\title{
The Model of Psychosocial Program to Restore the Cheerfulness of Post Disaster Students through Dompet Dhuafa 'Back To School' Program
}

\author{
Rina Fatimah, Yosa Novia Dewi and Nia Kurniasih
}

\begin{abstract}
Aceh is one of the provinces in Indonesia. In December 2016, Aceh was once again hit by an earthquake of 6.4 SR. This disaster gave deep traumatic impacts for residents. Dompet Dhuafa as one of the Amil Zakat Institute (LAZ) in Indonesia is an institution that focuses on post disaster recovery efforts in the form of psychosocial support. Psychosocial support provided to children is in the form of Back to School Program. The study was conducted in May 2017 in schools targeted by the program: Islamic Primary School (MIN) Panteraja, Islamic Primary School (MIN) Beuracan, and Islamic Junior School (MTsN) Meureudu. The sample in this study consisted of Principals, Teachers, Students, and shadow teachers of the program coming from 3 schools. The results showed that the Back to School program is effective in restoring the cheerfulness of post-disaster students with an effectiveness score of $90.2 \%$. Overall, the program is considered effective in improving students' happiness at school with $93 \%$ score, improving student learning motivation with score $88,9 \%$, and increasing literacy rate motivation with score $88,8 \%$. Even with some improvement recommendations, it can be concluded that this program can be used as a model program to restore the cheerfulness of post-disaster students impacted on the recovery of student trauma..
\end{abstract}

Keywords-Psychosocial Program, Back to school Program, Students' cheerfulness.

\section{INTRODUCTION}

Base on National Coal Freezing Timeline (2010) data, the strategic position of Indonesia as the world's largest archipelagic country has abundant potential and natural wealth. Indonesia is also gifted with area of 7.7 million $\mathrm{km} 2$, a land area of only $1 / 3$ of the ocean's width, the 4 th longest coastline in the world of $95,181 \mathrm{~km}$, and 13,466 islands (Sutisna 2012). The oceans which contain natural wealth and also the mountains stretching from Sabang to Merauke both active and inactive, give tremendous benefits for the country. However, on the other hand Indonesia is also one of the central areas of disaster. This is due to the geographical location of Indonesia which is a meeting place of the world's plates; Asia plates, the Continent of Australia, the Indian Ocean and the Pacific Ocean. In the southern and eastern part of Indonesia there is a

Rina Fatiumah, Bogor Agricultural University, Indonesia, Yosa Novia Dewi, Putra Indonesia University, YPTK Padang, Indonesia Nia Kurniasih, Dompet Dhuafa, Indonesia volcanic arc stretching from the island of Sumatra - Java Nusa Tenggara - Sulawesi, whose sides are old volcanic mountains and lowlands partly dominated by swamps (BNPB, 2011). Besides, Indonesia has a series of active volcanoes about more than 128 active volcanoes. Based on data from BNPB in 2011, the number of incidents of Indonesian natural disaster reached 1545 events, with the death victims reached 940 people and injured amounted to 294,124 people (BNPB, 2011). In macro scale disaster it can be divided into two that is caused by nature and human. Natural disasters caused by volcanic eruptions, earthquakes, landslides, tornadoes and floods, while social disaster in the form of social unrest (Triyono, 2012).

Various kind of disasters hit Indonesia either caused by the nature or human will definitely give negative impacts to its people. The impacts can be in form of physical destruction, asset loss, or psychosocial impact. In general, psychosocial impact can be seen from different level; individual, family and society with 3 different group response; (1) mild psychological distress which will be recovered within few days or weeks; (2) average or severe psychological distress which will be recovered as the time goes by; (3) people with mental disorder (WHO,2005). Furthermore, WHO (2005) suggests to provide intervention to basic psychosocial to society through varied sectors besides health. Psychosocial aspect is defined as dynamic relationship between psychology and social (Iskandar, et al, 2005).

There are 4 stages that someone will experience after the natural disaster happened. Those are: (1) Impact phase. At this phase, a victim may not show panic reaction. In fact he/she may not show overwhelming emotional response; (2) Inventory phase. At this phase the victim begins to calculate their losses while searching for the missing relatives. A gradually recovering consciousness followed by the reestablishment of social ties, to find separate families as well as to prepare for the anticipated negative feelings (sadness, anger, and others) can arise at any time; (3) Rescue Phase. At this phase, rescue aid begins to arrive. Victims get direction without challenge; (4) Recovery phase. This phase is marked by the resurgence of an emotional response that is commonly experienced by those who have just been hit by disasters. Sadness and even anger begin to become a common sight. They are uncooperative, and the victims' rejection of aid. 
These four phases do not take place on all victims since each individual has different endurance in dealing the disasters. It is possible that the disaster victims will move drastically from the first phase directly to the fourth stage (Megawangi \& Indragiri, 2006).

Aceh is one of the provinces in Indonesia. In December 2016, Aceh was once again hit by an earthquake of 6.4 SR. This disaster gave deep traumatic impacts for Pidie Jaya residents, Aceh. Natural disasters occurring in some areas have alarming consequences. Besides physical loss consequences, there are other unmeasurable consequences impacted on all sides of society's life. Traumatized people, unemployment, neglected children, separated families, fear and prolonged sadness, lost hope, life uncertainty and more are glance of real portray of disaster suffering. A thoroughly intervention is needed for disaster-victim communities to fulfill physical, psychological, spiritual and social needs, especially among children. Children aged five to ten are categorized as vulnerable to post-disaster psychological impacts. Therefore, various efforts are needed to overcome the impact of the disaster, either individually or in groups.

Rapid change from emergency response to the communities development is a priority in disaster management. The power of a society / community is the base in fostering feelings of mutual relationship, kinship and solidarity. Disaster management should be done in a sustainable way. Consequently, various efforts need to be conducted such as "prevention of anticipatory program through psychosocial intervention which is implemented in the socirty instead of hospital" (Hidayat, 2005; Iskandar et al, 2005).

Dompet Dhuafa as one of the Amil Zakat Institute in Indonesia is an institution that focuses on post disaster recovery efforts in the form of psychosocial support. Psychosocial support provided to children is in the form of Back to School Program. This study aims to determine the effectiveness of Back to School Program. Back to School Program is a recovery program for survivors of primary and secondary school students. Through psychosocial and student mentoring program, it is expected to restore the cheerfulness of the children, the spirit of learning and reducing the learning delay while they are in the evacuated location. The program has two objectives: (1) Continuing the post-disaster learning readiness program so as to achieve a sense of security; (2) Implementing a fun educational process by applying the National Education Curriculum (Fatimah, 2017).

Back to School Program had been implemented since January to May 2017. There are three schools benefited from the program, each school was assisted by two shadow teachers who were placed for 5 months. The activities provided during the program include psychosocial support for children, teacher training, and procurement of reading books and educational games.

Based on the formulation of the problem, the purpose of this research is formulated. This research is aimed to analyze the effectiveness of Psychosocial Back to School Program as The Model of Psychosocial Program for Children of disaster victims. This research is expected to be useful for some parties, including: (1) For the organizer of Dompet Dhuafa Program, this research is expected to be used as the evaluation material of the program so that the recommendation of improvement is obtained; (2) For government or other NGOs. This research is expected to be an effective description and comparison tool for post-disaster victims, especially for school-aged children.

\section{LITERATURE REVIEW}

\section{A. Post-disaster Impact}

Post Traumatic Stress Disorder (PTSD) may rise as a result of tremendous traumatic experiences. It may also become a mental disorder to someone after experiencing a traumatic experience in life or an event that threatens the safety of their soul. People experiencing as living witnesses are likely to experience stress disorders (Huppert, Bufka, Barlow, Gorman, Shear, \& Woods, 2001).

The lifetime prevalence of PTSD is 4\% and the incidence rate will be higher in the affected areas (DSM IV-TR, 2004). PTSD symptoms usually appear in the first to third months post-trauma, but may also appear in the prolonged years (delayed-onset PTSD). This situation, when not getting the right help and adequate psychosocial support, can develop into a mental disorder. The appropriate psychosocial recovery proces for individuals and communities is done through psychotherapy and pharmacotherapy with the aim of regaining normal functioning so that it remains productive and leads a meaningful life after a traumatic event (in Irmansyah, 2007; Iskandar et al., 2005).

\section{B. Post-Disaster Therapy}

Children need more mental resilience than adults in facing the disaster. Therefore, trauma healing is needed by children. Through the therapy, children are asked to discover or identify forms of trauma through expressions displayed in the game. For example, fear, anxiety, insomnia, and other fears that have not previously been experienced. To eliminate post-disaster anxiety, trauma healing cannot be conducted once instead of repeatedly and gradually (Komnas Anak, 2014).

Therapeutic techniques for post-disaster trauma recovery can also be done by ending the trauma flow direction through experience blocking so that children do not have the opportunity to develop the bitter experience in their dream creepy imagination. When such conditions occur, the effects of trauma will become more traumatic and lead to more severe psychiatric disorders. Experience blocking can be done by diverting and subordinating the focus of the child's attention to the disaster that befall them by providing activity substitution (activity substitution), either in the form of physical activity, psychic and spiritual social activities. This replacement activity is a canalization effort of all forms of negative experience due to disaster (Yahman, 2010).

\section{Post-Disaster Psychosocial Program}

Psycho is defined as the soul, mind, emotions / feelings, behaviors, believes, attitude, perception, self-understanding. Meanwhile, social refers to other people, order, norm, rule 
value, economic system, kinship system, religion prevailing in society. Psychosocial is defined as a dynamic relationship of interaction between human where the behavior, thoughts and emotions of the individual will influence and be influenced by others or social experience (Schultz \& Duane, 1997). Any interaction with other people or social events will affect the psychological condition of one individual. Cognitive and affection factors are shaped in situations, traditions, beliefs, patterns of relationships, values and norms that live in the society in which we are raised (Heni, 2008).

Treatment procedure mental health and post-disaster psychosocial problems in general can be divided into three stages. First, the emergency stage that takes place since first day of disaster until a few weeks later. At this stage most of the victims' societies will naturally be able to recover themselves. Psychological support from outside communities, including volunteers, will speed up the natural recovery. However, a few will experience psychological problems over an extended period of time. At the rehabilitation stage, efforts to restore mental and psychosocial status to them must be systematically implemented. The recovery efforts need to be done by institutions or professional workers either in mental and psychosocial health (Tim Crisis and Recovery Center, 2006)

\section{RESEARCH METHOLOGY}

\section{A. Time and Place of Research}

The study was conducted in 2017. The data was conducted in May 2017. Entry, processing, and data analysis were conducted in May - June 2017. The study was conducted in 3 (three) schools at Aceh (Indonesia) targeted by Back to School Program, Dompet Dhuafa. Those were: (1) Madrasah Ibtidayah Negeri (MIN) Panteraja; (2) Madrasah Ibtidayah Negeri (MIN) Beuracan; (3) Madrasah Tsanawiyah Negeri (MTsN) Meureudu.

\section{B. Population and Sample}

Population is a collection of all individuals whose surveys should be exploited (Lemeshow, 1990). The population in this study were academicians (Students, Teachers, and Principals) in 3 schools targeted by the program as well as the shadow program of Back to School. The samples in this research were: (1) Teacher sampling is done by the formula $1 / 2 \mathrm{~N}+1$ ( $\mathrm{N}=$ research population); (2) MIN Student sampling (Panteraja and Beuracan) is done by purposive sampling that is focused to all 5 th graders considering that higher level class can well understand research questionnaire. Besides, grade 6 had graduated / was not in school when the data were collected; (3) MTsN student sample is done with slovin formula: $\mathrm{N} / 1+\mathrm{Ne}^{2}(\mathrm{~N}=$ population, $\mathrm{e}=$ error rate $5 \%)$ with population focus on first and second grade students as third grade students had graduated when the data were collected.

TABEL I

RESEARCH SAMPLE

\begin{tabular}{clcc}
\hline No & \multicolumn{1}{c}{ Schools } & Teacher & Students \\
\hline 1 & MIN Panteraja & 11 people & 37 people \\
2 & MIN Beuracan & 9 people & 30 people \\
3 & MTsN Meureudu & 21 people & 185 people \\
\hline
\end{tabular}

\section{C.Research Design and Data Collection Techniqu}

The design of this study is cross sectional which is data collection technique (one of descriptive research methods) where information is collected only at a certain moment (Kountur, 2003). The data used in this study are primary data and secondary data. Primary data were collected by using questionnaire. The reliability test of the questionnaire shows the value of cronbach alpha is 0.6. This means that the questionnaire is reliable and valid to be distributed. In the meantime questionnaire containing student-level trauma identification was adopted from Post-Disaster Psychosocial Program Manual by Khasrismawan.

Primary data collection is done through direct interview and In Depth Interview. The instrument of this research consists of: 1) questionnaire; a structured question used to collect data characteristic of respondent; 2) Questionnaires containing statements about the effect of Back to School Programs to students; 4) An interview guide including questions about program implementation and its benefits (program evaluation, impressions and messages) (indepth interview guide). Meanwhile, secondary data was obtained through document analysis to school management.

\section{D.Research Design and Data Collection Techniqu}

The data obtained are processed through the process of editing, coding, scoring, data entry to computer, data cleaning, and data analysis. After all the data are entered to the computer it is then processed using SPSS for Windows version 20.0. The data will be analyzed using three methods, namely: (1) descriptive analysis; (2) quantitative analysis combined with qualitative analysis derived from the results of indepth interview. Descriptive analysis is used to describe the variables in this study consisting of the characteristics of respondents. Quantitative analysis is used to view categories of variables. The category level of each variable is measured by scoring technique and grouped with Class Interval Technique. The formula is:

Class Interval $(\mathrm{CI})=\underline{\text { Maximum Score }(\operatorname{Max})-\text { Minimum Score }(\text { Min })}$ Total category

Grouping categories are as follows: Low/Light $=$ Min until $($ Min + ICI; Fair $=($ Min $+\mathrm{CI})+1$ until $($ Min $+2 \mathrm{CI})$; High/heavy $=(\operatorname{Min} 2 \mathrm{CI})+1$ until Max

\section{RESEARCH RESULT}

\section{A. Respondent Identity}

The research was conducted in 3 schools. MIN students who became respondents in the study were all 5th graders. Meanwhile, MTsN students who became respondents in this study were $51 \%$ for the first grader and $49 \%$ for the second grader. The age distribution of MIN Panteraja and MIN Beuracan students who became respondents in this study ranged from 10-12 years. 90\% of MIN Panteraja students are mostly at the age of 11 years. Similarly there is $64 \%$ of MIN Beuracan students who are at the age of 11 years. Meanwhile, the age distribution of MTsN Meureudu students who became respondents in this study ranged from 12 to 15 years. $47 \%$ of respondents are at the age of 13 years. Meanwhile, students aged 14 years are around $43 \%$. 


\section{B. Respondent Identity MTsN Meureudu Students Traumatic Level Post Disaster}

The trauma test is only done to the respondent from MTsN Meureudu. The level of trauma in this study was divided into 3, namely: no trauma, mild trauma, and severe trauma. The results showed that female MTsN Meureud students were more vulnerable to trauma than male students. $37.4 \%$ of female students were still experiencing mild trauma but only $15,4 \%$ of students had mild trauma.

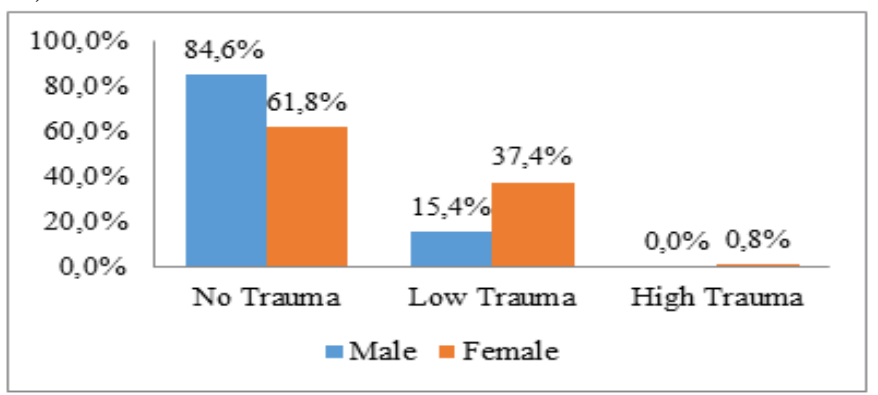

Fig. 1: Category of MTsN Meureudu Students level of trauma based on gender

In general, the results showed that there were $31.1 \%$ of students who experienced mild trauma and about $0.5 \%$ (1 female student) who had severe trauma. This is in line with the results of indepth interview with the teachers and shadow teachers mentioning that trauma symptoms were still visible although not too significant. For example, students were still afraid to remember the earthquake event. In fact, there were still students who cried and fainted during mild earthquakes.

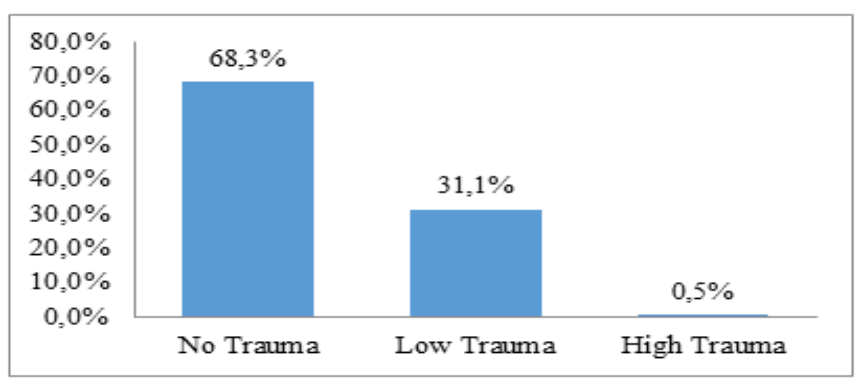

Fig. 2: Trauma Level Category of MTsN Meureudu students in general

\section{C. 'Back to School' Psychosocial Program Profile}

Back to School Psychosocial Program has several series of activities. Those are:

\section{a. Cheerful Class/Kelas Ceria (Learning Activities with Shadow Teachers)}

Kelas Ceria is one of the activities of the Back to School program. Kelas Ceria is implemented in order to restore the cheerfulness of children affected by the disaster. Kelas Ceria was held in 3 assisted schools. Kelas Ceria focuses only on the direct beneficiaries of the program that is the learners 3 schools. The field of learning taught focuses on two subjects namely the field of arithmetic or Mathematics and Language that is Indonesian language.

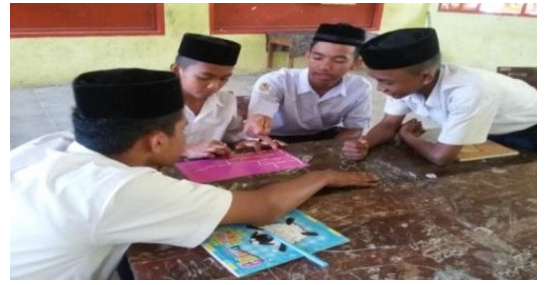

Fig. 3: Class activity cheerful with a Kelas Ceria approach

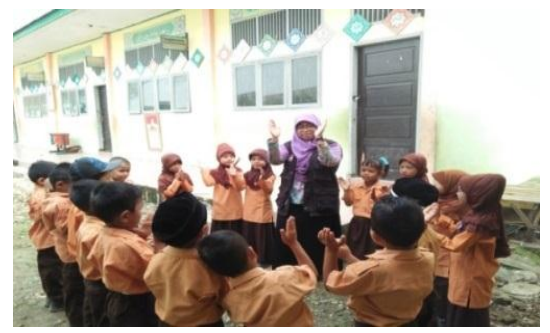

Fig. 4: Kelas Ceria conducted outside the class with the shadow teachers

\section{b. Happy Gymnastic}

Gymnastics conducted by the shadow teachers aims to provide a means of sports for students so that it restores the cheerfulness This activity was chosen as one of series of programs based on the phrase stating that mens san in corpore sano or in a healthy body there is a healthy soul.

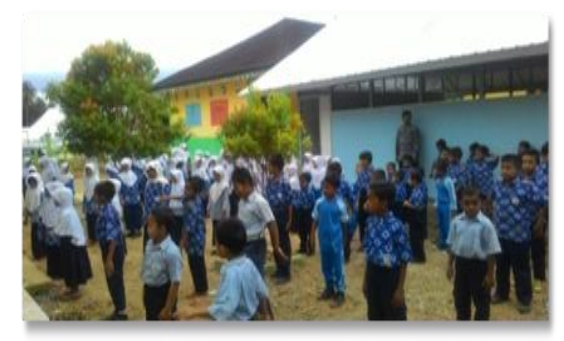

Fig. 5: Happy Gymanastic activity in MIN 21 Pidie Jaya followed by all students, teachers and shadow teachers.

\section{c. MTsN Students Training}

Training Activities for Students was only given to MTsN Meureudu students. This activity was conducted four times, namely: training I with the theme 'Trauma Healing with SEFT (Spiritual and Emotional Freedom Technique)' method, 2nd training with 'Super Great Memory' theme, 3rd training with 'Dream and Character Building' theme, and 4th training with 'Spiritual Motivation' theme.

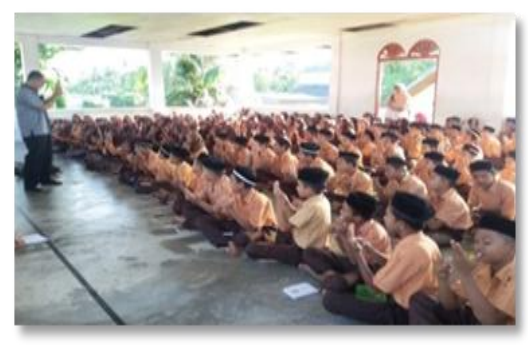

Fig. 6: Spiritual and Emotional Freedom Technique Training 


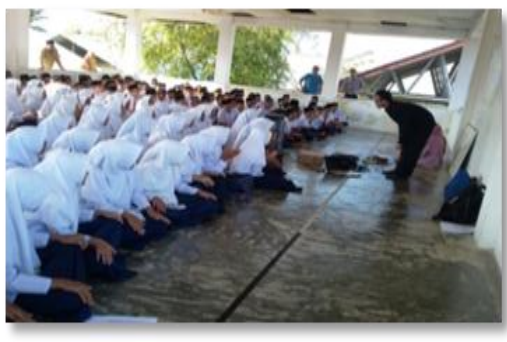

Fig. 7: Dream and Character Building Training

\section{d. Outbond}

Outbound activity aims to condition the students according to their original condition, where children are happy to compete. The first stage outbound activities conducted at MTsN Meureudu consisted of calligraphy contest, trilingual speech contest, MIPA Olympic and English Essay. In MIN Pentaraja, the outbound organized including the race to enter nail in bottle, marble relay, rubber relay, Mom and Kids, water relay, card games. While in MIN Beuracan outbound activities conducted were eating crackers games, coloring contest, filling water in a bottle, filling the emergency bag.

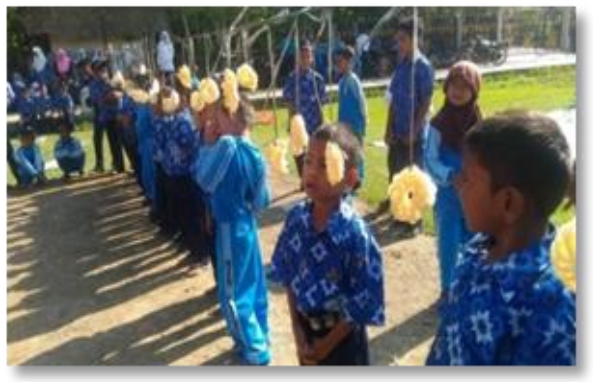

Fig. 8: Makan Kerupuk racing games among classes in MIN Pentaraja

\section{e. Assembly}

Assembly is the closing program of all 'Back to School' program from dompet dhuafa. This program is dedicated as an appreciation for the students' creativity. This event was followed by each grade of class from grade 1 to grade 6 for MI and grade 1 to grade 3 for MTs.

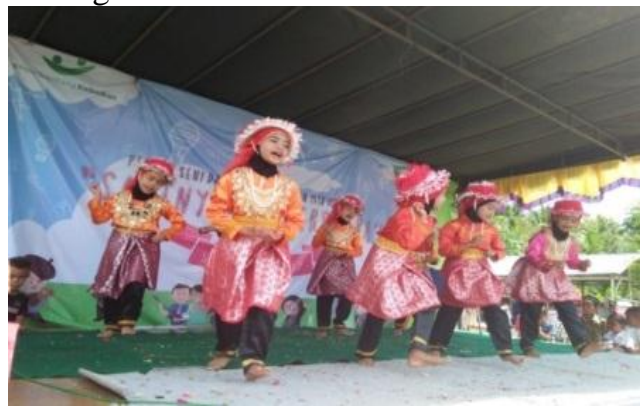

Fig. 9: Aceh Traditional dance performed in Assembly activity in Min Pentaraja

\section{f. Evaluation of Program Implementation}

Back to School Program for MIN students consists of 5 series of activities. However, during the data collection there were only 4 series of activities done, namely: 1). Learning with shadow teacher, 2). Outbond, 3). Gymnastics, and 4). Book reading. Meanwhile, the other activity that is assembly was conducted after the data collection.

\section{a. Students' Feeling after Conducting Series of Back to School' Program.}

The results showed that all 5th grade students of MIN Pentaraja were happy to follow all series of Back to School Program activities. Meanwhile, at MIN Beuracan, only learning programs with shadow teachers and reading activities were mostly prefered by all students. However, Outbond is preferable by $88 \%$ of students, $8 \%$ of students were unhappy and $4 \%$ of students felt fair. While gymnastics is preferable by $96 \%$ of students and the remaining 4\% felt unhappy.

\section{$b$. The Students' Interest to 'Back to School' Series of Activities.}

In general, MIN students have great interest to series of the program. This can be seen based on the results of student opinions on the program series. However, to see the order of interest, the students are asked to rank their interest to the program from the first until the fourth place.

TABLE II

THE ORDER OF STUDENTS INTEREST BASED ON THE RESEARCH RESULT

\begin{tabular}{llll}
\hline $\begin{array}{c}\text { The Rank of } \\
\text { Students' Interest }\end{array}$ & \multicolumn{1}{c}{ MIN Panteraja } & \multicolumn{1}{c}{ MIN Beuracan } & \multicolumn{1}{c}{ MTSN Meureudu } \\
\hline First place & Leaming with the shadow & Leaming with the shadow & Leaming with the shadow \\
& teachers & teachers & teachers \\
Second place & Literacy activity & Gymnastic & Outbond \\
Third place & Outbond & Literacy activity & Students training \\
Fourth place & Gymnastic & Qutbond & Assembly \\
\hline
\end{tabular}

c. Effectiveness of 'Back to School' Program to the Students

The effectiveness of the program is categorized based class interval formula as follow: Score $<60 \%=$ not effective; Score $60 \%-80 \%=$ less effective; Score $>80 \%=$ effective. The effectiveness of Psychosocial Program 'Back to School' is seen based on 2 variables, namely: (1) Program effectiveness on student happiness in school; (2) Program effectiveness on student learning motivation. The effectiveness of psychosocial program is also divided based on 2 respondents, namely: (1) Program effectiveness for students according to the students (Picture 10); (2) Program effectiveness for students according to teachers (Picture 11).

The effectiveness of the program for MIN Panteraja students are as follows: (1) The program is effective in improving the students' happiness after the disaster either from the students (100\%) and the teachers (99\%) point of view; (2) The program is effective in improving the students' motivation after the disaster either from the students (94\%) and the teacher (89\%) point of view; (3) The program is effective in improving the students' literacy motivation in reading either from the students $(96 \%)$ and the teacher $(95 \%)$ point of view (Picture 10 and Picture 11).

The effectiveness of the program for MIN Beuracan students are as follows: (1) The program is effective in improving the students' happiness after the disaster either from the students (97\%) and the teachers (91\%) point of view; (2) The program is effective in improving the students' motivation after the disaster either from the students (92\%) and the teacher (88\%) point of view; (3) This program is effective in improving the students' literacy motivation in reading either 
from the students $(96 \%)$, the teacher $(95 \%)$ point of view (Picture 10 and Picture 11).

The effectiveness of the program for MTsN Meureudu students are as follows: (1) The program is effective in improving the students' happiness after the disaster either from the students (99\%) and the teachers (89\%) point of view; (2) The program is effective in improving the students' motivation after the disaster either from the students (93\%) and the teacher (90\%) point of view; (3) The program is effective in improving the students' literacy motivation in reading either from the students $(84 \%)$ and the teacher $(86 \%)$ point of view (Picture 10 and Picture 11).

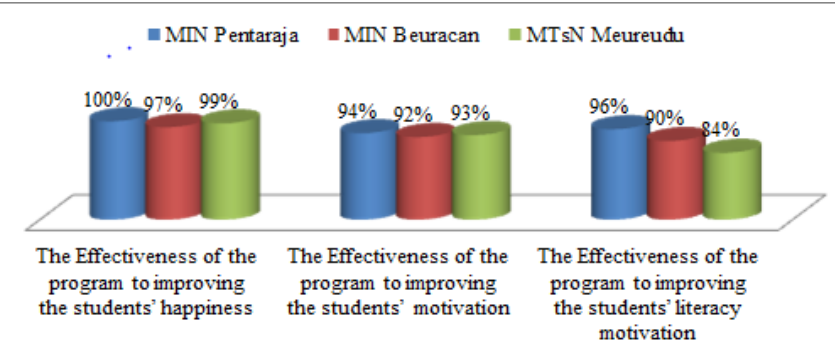

Fig. 10: The Effectiveness of the program to the students (students point of view)

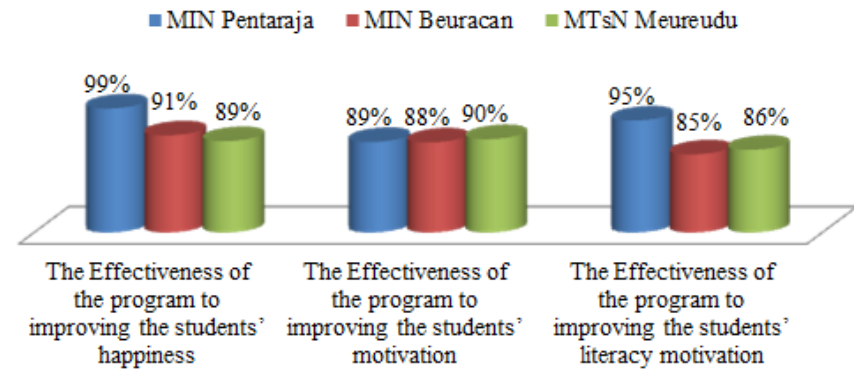

Fig. 11: The Effectiveness of the program to the students (teachers point of view)

\section{CLOSING}

Back to School Program conducted to 3 schools in Pidie Jaya had several series of activities; 1) Learning with shadow teacher, 2). Outbound, 3). Gymnastic, 4). Book reading activity, and 5) Students training for MTsN. The results show that generally, almost all students (more than $85 \%$ of students) involved in the activities. Moreover, Almost $100 \%$ of the students feel happy to participate in the activities conducted in Back to School program. Teachers' involvement in the activities is also good.

In general, the program is effective in restoring the cheerfulness of post-disaster students with an effectiveness score of $90.2 \%$. Overall, the program is considered effective in improving students 'happiness in schools with a score of 93\%, improving students' learning motivation by $88.9 \%$, and literacy motivation with score $88,8 \%$. This is in line with the results of interviews and in depth interviews with the teachers and assistants stating that students are more cheerful and enthusiastic in school after Back to School program is implemented in their schools. This cheerfulness and passion is shown by the students during their participation in the series of activities and with the intensity of attendance at post-disaster schools. Regardless with some recommendations for the program improvement, it can be concluded that this program can be used as a model to restore the cheerfulness of postdisaster students that have an impact on students trauma recovery.

\section{REFERENCES}

[1] BNPB. 2011. Potensi Ancaman Bencana. [diunduh 2012 Januari 19]. Tersedia di http:// www.bnpb.go.id/website/asp/content.asp?id=31.

[2] Fatimah, R. 2017. Deskripsi Program Kembali Bersekolah. Bogor: Dompet Dhuafa.

[3] Hidayat, A.A. (2005). Model Penelitian Kesehatan. Jakarta: PT. Rineka Cipta.

[4] Huppert, J.D., Bufka, L.F., Barlow, D.H., Gorman, J.M. Shear, M.K., \& Woods, S.W. (2006). Therapists, therapists' variables, and cognitive behavior therapy outcome in a multicenter trial for panic disorder. Journal of Consulting and Clinical Psychology, 69, 747-755 https://doi.org/10.1037/0022-006X.69.5.747

[5] Irmansyah. (2007). Stres pascatrauma bisa menjadi gangguan jiwa. [diunduh 2007 Juli 16]. Tersedia di www.kompas.com/ver

[6] Iskandar, L., et al. 2005. Prinsip-prinsip Dukungan Psikososial Pascabencana. Jurnal Aksi Sosial (JAS). Edisi Disaster Manajemen

[7] Kountur, R. 2003. Metode Penelitian untuk Penulisan Skripsi dan Tesis. Jakarta: PPM

[8] Kharismawan, K. . Panduan Program Psikososial Pasca Bencana. Fakultas Psikologi Unika

[9] Lemeshow, Stanley, et. Al. 1990. Besar Sampel dalam Penelitian Kesehatan. Yogyakarta: Gadjah Mada University Press

[10] Megawangi, R., R. Indragiri. 2006. Membantu Anak Pulih dari Trauma. Jakarta: Republika.

[11] Triyono. 2012. Pengembangan Transmigrasi Bencana Alam di Indonesia dalam Perspektif Sosial. Vol. 29 No. 1 Juli 2012. Jakarta: Jurnal Ketransmigrasian.

[12] Sutisna, D. H. 2012. Potensi Kelautan Mampu Menyejahterakan Rakyat. [diundu 2014 Juli 1]. Tersedia di http://www.dekin.kkp.go.id/

[13] Schultz, Duane. 1997. Growth Psychology: Models of the healthy personality. D. Van Nostrand Company: New York

[14] World Health Organization-Regional South East Asia. (2005). WHO framework \& evaluation for mental health and support after the tsunami. Geneva: WHO

[15] World Health Organization (WHO). (2005). Catatan tentang bantuan psikososial/Kesehatan Mental untuk daerah yang terkena tsunami. Tersedia www.who.int/mental_health/resources/en/training_guidelines

[16] Yahman, S, A. 2010. Bangun Imunitas Psikologi. [diunduh 2014 Juli 4]. Tersedia di http://m.suaramerdeka.com 